\title{
THE ANALYSIS OF SCIENCE TEXTBOOK FOR FIFTH GRADE OF ELEMENTARY SCHOOL IN SAMBONG SUB- DISTRICT, DISTRICT OF BLORA BASED ON SCIENTIFIC LITERACY ASPECTS
}

\author{
Isna Ida Mardiyana ${ }^{1}$, Tise Karisma Triya Hardiani ${ }^{2}$, Mujtahidin ${ }^{3}$ \\ ${ }^{1,3}$ Lecturers of Elementary School Teacher Education Department, Trunojoyo University \\ ${ }^{2}$ Student of Elementary School Teacher Education Department, Trunojoyo University \\ najwazka@gmail.com,muji.pgsd11@gmail.com, tisyekarisma@gmail.com
}

\begin{abstract}
This study aims to explain scientific literacy aspects on science textbook for fifth grade used for Elementary School. Scientific literacy aspects involve (1) the knowledge of science, (2) the investigative nature of science, (3), science as the way of thinking, and (4) interaction of science, technology and society. The approach of this study was qualitative. This study used purposive sampling and the observed samples were three science textbooks that most used at Elementary School in Sambong Sub-District, District of Blora. The data of this study were obtained by using technique of documentation study based on scientific literacy aspects. The data analysis was done using descriptive statistics with percentage calculation. The result of this study showed that scope of scientific literacy aspects on books that were analyzed, especially in Biology, were $67,4 \%$ contains of the knowledge of science, $16,8 \%$ contains of the investigative nature of science, $13,3 \%$ contains of science as the way of thinking, and $2,5 \%$ contains of interaction of science, technology and society. The result of analysis indicated that books used were not show the balance of scientific literacy aspects where science as the body of knowledge aspect is still much greater than three other aspects.
\end{abstract}

Keywords: textbook, scientific literacy, Elementary School 


\section{Introduction}

Scientific literacy is an individual's ability to master knowledges and sciences. According to Organization for Economic Cooperation and Development (OECD) in Sandi et al. (2012: 94), scientific literacy is defined as the capacity to use scientific knowledge, identify questions and draw conclusions based on facts to understand the universe and make decisions from changes that occur due to human activities. Scientific literacy is not only emphasized on mastering knowledge but how mastery of knowledge is applied in life through scientific processes and ways of thinking.

Mastery of scientific literacy cannot appear in a short time, but it takes a long time to be able to master all aspects. Through learning Natural Science, students are expected to be able to develop scientific literacy skills. Sandi, et al. (2012: 94) stated that the orientation of comprehensive scientific literacy formation should be applied to children from an early age, especially considering the growth and development of children. The role of children as students will be very vital in the future, because cultural development (science and technology, social community, etc.) of the nation will be carried out later by these children. Students in Indonesia, through mastering scientific literacy, are expected to be able to master science and technology that are very useful, both for themselves, society and the nation's improvement.

Based on the results of scientific literacy studies conducted by PISA, it can be seen that the level of Indonesian children's scientific literacy is still very low. The latest research conducted by PISA in 2015 showed that Indonesia is ranked 67th out of 75 participating countries, which means that Indonesia is ranked the bottom 9th of all PISA participating countries. The average score obtained by Indonesia is only around 400 points. Rustamam in Wulandari and Sholihin (2016:2) explained that Indonesian students with achievement of scientific literacy score around 400 points means that they are only able to remember scientific knowledge based on simple facts (such as names, facts, terms, simple formulas) and use general scientific knowledge to draw or evaluate a conclusion.

According to Kurnia et al. (2014: 43), the low ability of scientific literacy of Indonesian students is influenced by many things, including curriculum and education system, selection of teaching methods and models by teachers, learning tools and facilities, learning resources, teaching materials and so on. One factor that relates directly to student's learning activities and influences the low scientific literacy skills of Indonesian students is the existence of learning resources in form of books which still being the main source of students learning in schools. According to Stake and Easley in a journal written by Adisendjaja (2009: 2), stated that $90 \%$ of science teachers use books in the teaching and learning process. The reality in the field reveals that during the learning process, both teachers and students fully guided by the books they have, starting from delivery of the material to other learning activities such as giving assignments both at school and at home.

A good science textbook should contain three main components of scientific literacy, namely content, process and context. Content relates to facts, definitions, concepts, theories, models and terminologies. Process relates to the ability to obtain and find content, while context relates to the benefits of science for individual and society life. But the reality shows that the textbooks used have not fulfilled the balance portion of scientific literacy within them. Many of books used in learning only emphasize science content, while lack of process and context. According to Firman in Sandi et al. (2012: 95), science textbooks in Indonesia emphasize the dimension of content rather than process and context, so this condition causes low levels of Indonesian children's scientific literacy.

Analysis of textbooks serves as one of the guarantors of the increasing quality of educational outcomes (Tarigan in Mariah, 2014: 9). Previous research on aspects of scientific literacy in textbooks has often been conducted especially among middle and high school students, because, indeed, the research subject used by PISA is students aged 15 years, which means they are in middle and high school. There are four aspects that serve as guidelines for analyzing scientific literacy aspects in science textbooks, namely the knowledge of science, the investigative nature of science, science as a way of thinking and interaction of science, technology and society.

The selection of textbooks which includes the scope of good scientific literacy aspects is a first step that teachers can do to build scientific literacy of students in Elementary School, so it is important for a teacher to understand the scope of scientific literacy aspects of the textbooks used. Previous 
studies on the analysis of textbooks, based on scientific literacy aspects that are more often held in junior and senior high school and based on background exposure, has invited interest for researchers. Considering that in Elementary School there is also natural science subject, it means that the development of scientific literacy skills can also be given since children are in Elementary School through the selection of the right science textbooks.

The purpose of this study is to obtain information about the scope of scientific literacy aspects in science textbooks at fifth grade of Elementary School in the field of Biology, considering science subject in Elementary School is consist of various fields. The material selection in the field of Biology is based on previous research which revealed that the scope of the most unbalanced aspects of scientific literacy is in the field of Biology.

Based on the background of the problems that have been explained above, the statement of the problem in this study is "How is the scope of science textbooks in fifth grade of Elementary School in terms of aspects of the knowledge of science, the investigative nature of science, science as a way of thinking, and interaction of science, technology and society?".

\section{Method of The Study}

The type of research used in this study is descriptive research with documentation method. The object of this study is the most used science textbooks in Elementary School, especially in Sambong sub-district. The textbooks that will be analyzed are the three most used textbooks based on the results of the survey, namely Integrated Thematic Book Year 2013 published by the Ministry of Education and Culture) (code A), Science Book (for fifth grade of Elementary School) published by Erlangga (code B), and Natural Science Book published by BSE of National Education Ministry (code C) is as much as one subject in full.

The analysis is done by observing and understanding the elements of the text contained in the book based on the guideline of document study that have been made by the researchers. The guideline contains indicators of scientific literacy aspects developed by Chiapetta 2007. List of elements or units analyzed are complete paragraphs, questions, pictures, tables and their descriptions, short comments and direct activities (Chiapetta, 1991). The indicators of scientific literacy aspects can be seen in Table 1.

Table 1. Scientific Literacy Aspects

\begin{tabular}{|c|c|}
\hline Aspect & Indicator \\
\hline $\begin{array}{l}\text { The knowledge of } \\
\text { science }\end{array}$ & $\begin{array}{l}\text { 1. facts, concepts, laws, and principles } \\
\text { 2. hypotheses, theories, and models } \\
\text { 3. questions asking for recall of information }\end{array}$ \\
\hline $\begin{array}{l}\text { The investigative nature } \\
\text { of science }\end{array}$ & $\begin{array}{l}\text { 1. learns through the use of materials } \\
\text { 2. learns through the use of tables and charts } \\
\text { 3. makes calculations } \\
\text { 4. reasons out an answer } \\
\text { 5. participates in a thought experiment } \\
\text { 6. gets information from the Internet }\end{array}$ \\
\hline $\begin{array}{l}\text { Science as a way of } \\
\text { thinking }\end{array}$ & $\begin{array}{l}\text { 1. describes how a scientist discovered or experimented } \\
\text { 2. shows historical development of ideas } \\
\text { 3. illustrates empirical basis of science } \\
\text { 4. models the use of assumptions } \\
\text { 5. employs inductive or deductive reasoning } \\
\text { 6. shows cause and effect relationships } \\
\text { 7. gives evidence and proof } \\
\text { 8. presents methods of science and problem solving }\end{array}$ \\
\hline $\begin{array}{l}\text { Interaction of science, } \\
\text { technology and society }\end{array}$ & $\begin{array}{l}\text { 1. describes usefulness of science or technology } \\
\text { 2. presents negative effects of science or technology } \\
\text { 3. addresses societal issues related to science or technology } \\
\text { 4. discusses careers in science or technology }\end{array}$ \\
\hline
\end{tabular}


Analysis of each book was done by the researchers, then the results of the analysis were submitted to other observers to determine the tolerance of differences in observation using the observational reliability testing technique. The obtained data were included in the table of agreement contingency. The Agreement Coefficient was then calculated using the rough suitability index formula (Arikunto, 2016: 244). The categories are: Agreement Coefficient $<0.4$ : bad; $0.4 \leq$ Agreement Coefficient $\leq 0.75$ : good; $>0.75$ : very good (Chiapetta, 1991).

\section{Results and Discussion}

The results of the analysis show that the Agreement Coefficient between researchers and other observers obtain very good criteria of observation. The result of the agreement observation in book A is 0.94 , in book $\mathrm{B}$ is 0.92 , and in book $\mathrm{C}$ is 0.89 . This shows that the results of the researchers' analysis observed by other observers have a very good level of observation.

The results of the analysis of scientific literacy aspects in the science textbooks used in fifth grade can be seen in Table 2.

Table 2. Number and Percentage of Scientific Literacy Aspects in Book A, B, and C

\begin{tabular}{|c|c|c|c|c|c|c|c|c|c|}
\hline \multirow[b]{2}{*}{ No. } & \multirow[b]{2}{*}{$\begin{array}{c}\text { Scientific } \\
\text { Literacy Aspect }\end{array}$} & \multicolumn{2}{|c|}{ Book A } & \multicolumn{2}{|c|}{ Book B } & \multicolumn{2}{|c|}{ Book C } & \multirow[b]{2}{*}{$\underset{\substack{\text { Stateme } \\
\text { nt }}}{\sum}$} & \multirow[b]{2}{*}{$\begin{array}{c}\text { Avera } \\
\text { ge } \\
(\%)\end{array}$} \\
\hline & & $\begin{array}{c}\sum_{\text {State }} \\
\text { ment }\end{array}$ & $\begin{array}{l}\text { Percent } \\
\text { age }(\%)\end{array}$ & $\sum_{\substack{\text { Stateme } \\
\text { nt }}}$ & $\begin{array}{c}\text { Percentag } \\
\text { e } \\
(\%)\end{array}$ & $\sum_{\substack{\text { Stateme } \\
\text { nt }}}^{\sum_{\text {natem }}}$ & $\begin{array}{c}\text { Percentag } \\
\text { e } \\
(\%)\end{array}$ & & \\
\hline 1. & $\begin{array}{l}\text { The knowledge of } \\
\text { science }\end{array}$ & 32 & 61,5 & 39 & 79,6 & 11 & 61,1 & 82 & 67,4 \\
\hline 2. & $\begin{array}{l}\text { The investigative } \\
\text { nature of science }\end{array}$ & 14 & 26,9 & 6 & 12,2 & 2 & 11,1 & 22 & 16,8 \\
\hline 3. & $\begin{array}{l}\text { Science as a way } \\
\text { of thinking }\end{array}$ & 5 & 9,6 & 4 & 8,2 & 4 & 22,2 & 13 & 13,3 \\
\hline 4. & $\begin{array}{l}\text { Interaction of } \\
\text { science, } \\
\text { technology and } \\
\text { society }\end{array}$ & 1 & 1,9 & 0 & 0 & 1 & 5,6 & 2 & 2,5 \\
\hline & Total & 52 & 100 & 49 & 100 & 18 & 100 & 119 & 100 \\
\hline
\end{tabular}

The scope of four aspects of scientific literacy in Book A, Book B, Book C, and the average proportion of those three books can be seen in Picture 1, Picture 2, Picture 3, and Picture 4.

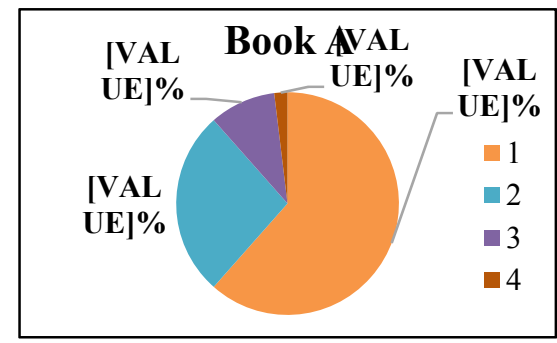

Picture 1. Scope of Scientific Literacy Aspects in Book A

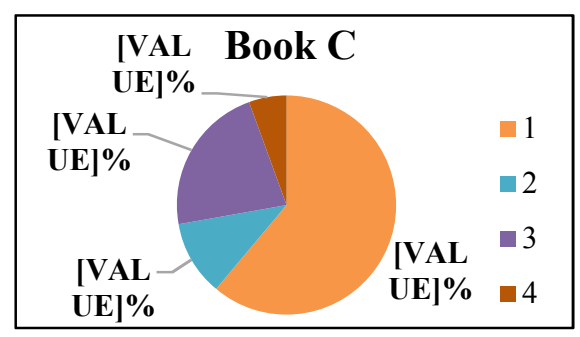

Picture 3. Scope of Scientific Literacy Aspects in Book C

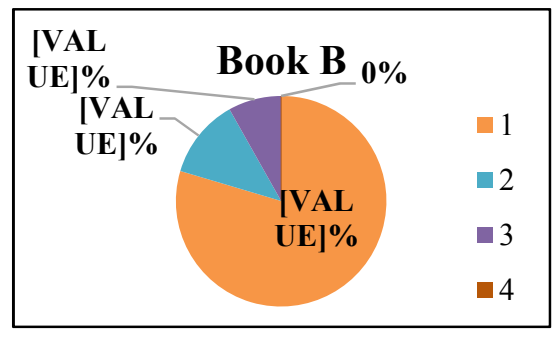

Picture 2. Scope of Scientific Literacy Aspects in Book B

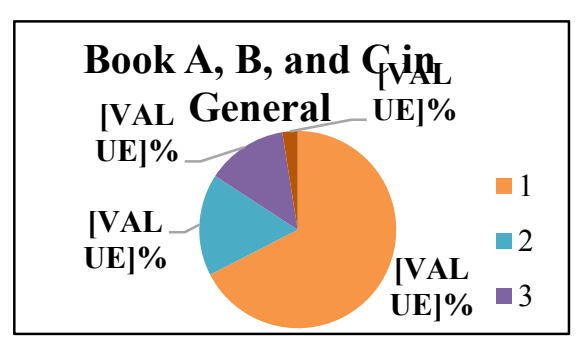

Picture 4. Scope of Scientific Literacy Aspects (Book A, B, and C) in General 


\section{Information:}

1. The knowledge of science

2. The investigative nature of science

3. Science as a way of thinking

4. Interaction of science, technology and society

Based on the results of the study that has been done, the most emerging or dominating aspects of scientific literacy from the total textbooks analyzed is the knowledge of science aspect, with a percentage of occurrence is $67.4 \%$ from the total number of analysis. Thus, in general, the science textbooks, in the field of Biology used in these three Elementary Schools, emphasize more on the knowledge of science aspect or on the scientific concept dimension. According to PISA $(2000,2003$, and 2006) in Rustaman (2012: 1.140), this dimension relates to how students are able to understand a number of key concepts in order to conceive certain nature phenomena and changes that occur due to human activities. Indeed, this is related to the knowledge of science. The condition, in which the knowledge of science aspect is more dominating, is common condition in the science textbooks used. Not only in science textbooks in the field of Biology, but in other fields. This is in accordance with the research conducted by Wahyu (2015) on the textbook in the field of Physics, and Retno (2017) on textbook in the field of Chemical that are more focused on the knowledge of science aspect.

The unit of analysis that most often appears in the knowledge of science aspect are statements that present the facts, concepts, principles, and laws contained in the Natural Science. These statements are the most dominating statements of all books analyzed, both book A, book B and book C. Adisendjaja (2009: 101) explained that if we look at the facts on the field, students in Indonesia are very good at memorizing, but most of them are less skilled in applying the knowledge they have. This is possible because students' learning habits are only limited to memorizing method to master knowledge and information. Ideally, good learning not only emphasizes abstract and conceptual learning, but also on active learning. However, in reality, there is no balance between the two things in the science lesson, especially in the textbooks that guide the learning process. If it is related to the goal of learning science in Elementary School, books that contain more aspects of the knowledge of science mean emphasizing learning that is oriented to mastering science products.

In addition to the dimension of scientific concepts, there is also dimension of scientific process in scientific literacy. The Dimension of Process examines students' ability to use scientific knowledge and understanding such as the students' ability to search, interpret and find scientific evidence. When related to aspects of scientific literacy, the investigative nature of science aspect and science as a way of thinking aspect belong to this dimension. Aspects of the investigative nature of science and science as a way of thinking, in Nature Science textbooks for fifth grade which were analyzed successively, had a percentage of occurrence of $16.8 \%$ and $13.3 \%$. Based on these results it can be said that scientific literacy aspects which represent the dimension of the scientific process are still not balanced when compared to the first aspect of scientific literacy, namely the knowledge of science aspect. Thus, science textbooks used in fifth grade, especially in the field of Biology, still emphasize on the aspect of knowledge and have not emphasized the process skills related to aspects of the investigative nature of science and science as a way of thinking.

According to Nur in (Adisendjaja, 2009: 10), process skills are the skills needed to become or work as a scientist. Mastery of knowledge with skills has a very close connection. Knowledge or concept of science can be mastered through the development of science process skills. The concept learning through the process skills approach aims to notice the learning about scientific concepts through the development of science process skills. Therefore, the essence of Nature Science as a product and a process can be developed through science learning.

The type of unit of analysis that appear in the dimension of scientific process includes activities related to scientific method and problem solving. Presentation of material in the textbook, indirectly giving answers or conclusions but first asking students to do activities and thoughts, is very appropriate. These activities can help students to practice the process skills and thinking skills to solve 
a presented problem. From these activities, students can build their own ability to think, find and transform complex information, and check the new information that obtained in accordance with the rules. But, unfortunately, the scope of the process skills in the science textbooks used in fifth grade is not yet emphasized.

The dimension of scientific context and areas of application is the third dimension in scientific literacy. The dimension of contex relates to interaction of science, technology, and science aspect. The scope of scientific context dimension more emphasizes on daily life than in the classroom or laboratory. This aspect illustrates the usefulness of science and technology for the society, shows the negative effects of science and technology for society, discusses social issues related to science and technology, and mentions careers in the field of science and technology. This section is actually a very interesting part for students to learn, because in this section presents events or objects that students may encounter frequently in daily life and explained based on science related to benefits, impacts, issues and careers. This will increase students' interest in learning Nature Science and as a strengthening step towards the concept of science. However, the results of the analysis on the science textbooks for fifth grade of Elementary School showed that the scope of interaction of science, technology and society aspect was very less emphasized with the percentage of occurrence of $2.5 \%$ only.

The types of statements that appear in the dimension are more accentuate how the usefulness of science and technology for society. This relates to science products that are useful for people's lives, but in negative impacts, social issues, and careers in the field of science and technology are less emphasized. Campble in Wahyu (2015: 6) stated that good textbooks can connect each material with scientific research as well as science, technology, and society with more emphasize how the aspects of science and the role of science in life, and mentioning careers related to material so students have views on related careers.

In theory, there is no standard provision that regulate the amount of scope of each scientific literacy aspect in a science textbook. However, if the presentation of the knowledge of science aspect (science content) has much greater scope than other aspects, it is feared that it will affect the student learning system or learning in the classroom. The learning process will only lead to science content rather than the scientific process that involves students in the investigative nature of science and the way of thinking in science. When the process skill possessed by students is low, it is likely that students will experience difficulties in applying science in real life, so that the ability in the fields of science, technology, and society will also be difficult to develop. According to Wilkinson (1999), the scientific literacy aspects that close to a balanced portion are $42 \%$ for the knowledge of science aspect, $19 \%$ for the investigative nature of science aspect, $19 \%$ for science as a way of thinking, and $20 \%$ for interaction of science, technology and society aspect.

In essence, Nature Science is built on the basis of scientific products, and scientific attitudes. In addition, Nature Science is also seen as a process, as a product and as a procedure (Trianto in Rofiyatun, 2015: 12). Science or Nature Science is associated with how to systematically find out about natural phenomena. The true Nature Science is not only emphasizes on the mastery of concepts, facts, theories or laws of science, but is also a process of discovery. The aim of learning science is to provide a mode for students to learn themselves, the natural surroundings, and the further development purpose is to apply it in daily life. In this case, ideally, science learning not only emphasizes the dimension of content, but it would also be better to put more emphasis on the dimensions of the process of science and the context of science.

\section{Conclusion}

\section{a. Conclusion}

Based on the results of the analysis of scientific literacy aspects in the science textbooks used in fifth grade of Elementary Schools in three schools, it can be seen that the books have included four aspects of scientific literacy, but from the three books analyzed did not show the balance scope of scientific literacy aspects. From the three books analyzed based on scientific literacy aspects, the 
following results were generally obtained: (1) the knowledge of science aspect is $67.4 \%$, (2) the investigative nature of science aspect is $16.8 \%$, (3) science as a way of thinking aspect is $13,3 \%$, and (4) interaction of science, technology and society aspect is $2.5 \%$. The average score of observation's agreement coefficient from the three books analyzed was 0.92 with a very good category.

The results showed that the science textbooks used in fifth grade of Elementary School, especially in the field of Biology, had a scope that is more oriented to the knowledge of science aspect and very less in terms of the presentation of interaction of science, technology and society. In the aspect of the investigative science and science as a way of thinking, tend to almost have the same scope, but the investigative science aspect has been less emphasized than the science as a way of thinking aspect.

\section{b. Suggestions}

Related to this study, there are several things that can be suggested to several related parties, are as follows.

1. For teachers, they should understand the scope of scientific literacy aspects as a basis for selecting books that contain balanced literacy aspects as teaching materials. In addition, in the learning process, the teacher should more empahize on the scientific process that covers investigative science and science as a way of thinking, and also emphasize on the context of science relates to interaction of science, technology, and society even though the textbooks used are more emphasize on the content of science or the knowledge of science.

2. For the authors, the writing of Nature Science books, especially for Elementary School, besides referring to the curriculum, it also refers to the aspect of science literacy.

3. For other researchers who want to conduct similar studies, it is expected to better understand the indicators of scientific literacy aspects first and thorough when categorizing each unit of analysis from a book. In addition, the analysis should be carried out on other field contained in the Nature Science textbook used in Elementary School, considering that in Elementary School, Biology, Chemistry, and Physics are summarize into one and known as Nature Science.

\section{References}

[1] Arikunto, Suharsimi, "Prosedur Penelitian Suatu Pendekatan Praktik," Rineka Cipta, 2016.

[2] Analisis Buku Ajar Biologi SMA Kelas X di Kota Bandung Berdasarkan Literasi Sains, https://journal.unnes.ac.id/sju/index.php/jise/article/download/9902/6349/ Retrieved 23 October, 2017.

[3] Chiappeta, E.L., Fillman, D.A, Sethna, G.H., "A Method to Quantify Major Themes of Scientifict Titeracyin Science Textbook," Journal of Research in Science Teaching 28 (8), 713-725 (1991).

[4] Chiappeta, E.L., and Fillman D.A., "Analysis of Five High School Biology Textbooks Used in The States for Inclusion of the Nature Science," Journal of Research in Science Teaching 29 (15), 1847-1868 (2007).

[5] Analisis Bahan Ajar Fisika SMA Kelas XI di Kecamatan Indralaya Utara Berdasarkan Kategori Literasi Sains, http://ejournal.unsri.ac.id/index.php/jipf/article/download/1263/419/ Retrieved 23 October, 2017.

[6] Analisis Aspek Literasi Sains Pada Buku Teks Pelajaran IPA Kelas V SD, http://ejournal.upi.edu./index.php/mimbar/ Retrieved 22 October, 2017.

[7] Analisis Literasi Sains Pada Buku Siswa Tematik Terpadu Untuk Siswa SD/MI Kelas IV kurikulum 2013, http://repository.ut.ac.id/5593/1/2014_29.pdf/ Retrieved 24 October, 2017.

[8] Sandi, M.I. et al., “Analisis Buku Ajar Fisika SMA Kelas X di Kota Bandung Berdasarkan Komponen Literasi Sains," Prodi Pendidikan Fisika FPMIPA, Universitas Pendidikan Indonesia, 2012.

[9] Analisis Kemampuan Literasi Sains Pada Aspek Pengetahuan dan Kompetensi Sains Siswa SMP Pada Materi Kalor, https://media.neliti.com/media/publications/60036-ID-analisis-kemampuan-literasi-sainspada-a.pdf/ Retrieved 22 October, 2017.

[10] Rustaman, Nuryani et al., “Materi dan Pembelajaran IPA SD,” Universitas Terbuka, 2012.

[11] Analisis Buku Siswa Mata Pelajaran IPA Kelas VIII SMP/MTs Berdasarkan Kategori Literasi Sains, http://fkip.unsri.ac.id/index.php/menu/1/ Retrieved 1 November, 2017.

[12] Wilkinson, J., "A Quantitative Analysis of Physics Texttbook for Scientifict Literacy Themes," Research in Science Education. 29 (3), 385-399 (1999). 